\title{
Pengaruh Level Energi dan Protein dengan Bakteri Bacillus amyloliquefaciens sebagai Probiotik untuk Mengurangi Pencemaran Amonia pada Kandang Ayam broiler
}

\section{The Influence of Energy and Protein Level with Bacillus amyloliquefaciens as Probiotics for Reducing Ammonia Contamination in Broiler Chicken Pens}

\author{
H. Riza ${ }^{1^{*}}$, Wizna ${ }^{2}$, Y. Rizal ${ }^{2}$ dan Yusrizal ${ }^{3}$ \\ ${ }^{1}$ Program Studi Ilmu Peternakan Fakultas Peternakan Universitas Andalas \\ ${ }^{2}$ Fakultas Peternakan Universitas Andalas \\ ${ }^{3}$ Fakultas Peternakan Universitas Jambi \\ *E-mail: heldariza@yahoo.com
}

(Diterima: 12 Januari 2018; Disetujui: 28 Maret 2018)

\begin{abstract}
Penelitian ini bertujuan bakteri Bacillus amyloliquefaciens dapat mengurangi pencemaran amonia pada kandang ayam broiler. Metode penelitian yang digunakan adalah eksperimental menggunakan Rancangan Acak Lengkap Pola Faktorial 3x 3 dengan 3 ulangan dan 2 faktor. Faktor A level energi (H1 $3000 \mathrm{kkal} / \mathrm{kg}$ ), (H2 $2900 \mathrm{kkal} / \mathrm{kg}$ ), (H3 $2800 \mathrm{kkal} / \mathrm{kg}$ ). Faktor B level protein (R1 $22 \%$ ), (R2 $20 \%$ ) dan (R3 18\%). Parameter yang diukur adalah Kadar ammonia, kadar air ammonia dan $\mathrm{pH}$ ammonia. Hasil penelitian menunjukan kombinasi level energi dan level protein serta interaksi kedua faktor signifikan ( $\mathrm{P}<$ $0,05)$ terhadap kadar ammonia, kadar air dan $\mathrm{pH}$ ammonia. Hasil penelitian ini dapat disimpulkan bahwa kombinasi energi protein yaitu $2800 \mathrm{kkal} / \mathrm{kg}$ : 18\% dan bakteri Bacillus amyloliquefaciens lebih efektif untuk mengurangi pencemaran amonia pada kandang ayam broiler.
\end{abstract}

Kata kunci: ammonia, Bacillus amyloliquefaciens, broiler, probiotik

\section{ABSTRACT}

The aim of this study was to use bacteria Bacillus amyloliquefaciens for reducing ammonia contamination in broiler chicken pens. The research method was used experimental using the Completely Randomized Design of $3 \times 3$ Factorial Pattern with 3 replications and 2 factors. Factor A energy level (H1 3,000 kcal/kg), (H2 2,900 kcal/kg), (H3 2,800 kcal/ kg). Factor B protein level (R1 22\%), (R2 20\%) and (R3 18\%). Parameters measured were ammonia, ammonia water content and ammonia $\mathrm{pH}$. This result showed that the combination of energy level and protein level and interaction of both significant factors $(P<0.05)$ against ammonia, water content and pH ammonia. The conclusion is combination of protein energy that is $2800 \mathrm{kcal} / \mathrm{kg} \mathrm{18 \%}$ and bacteria Bacillus amyloliquefaciens more effective to reduce the contamination of ammonia in broiler chickens.

Keyword: ammonia, Bacillus amyloliquefaciens, broiler, probiotic

\section{PENDAHULUAN}

Peningkatan permintaan konsumen terhadap daging ayam memicu meningkatnya jumlah populasi ayam broiler di Indonesia, salah satunya di Kota Padang. Peningkatan populasi ayam broiler akan memberikan dampak positif bagi ketersediaan daging di Padang, tetapi juga memberikan dampak negatif bagi ayam broiler, manusia dan lingkungan. Hal ini disebabkan karena bau dan efek merugikan yang ditimbulkan oleh gas ammonia $\left(\mathrm{NH}_{3}\right)$, sebagai akibat dari hasil metabolisme oleh mikroba dalam ekskreta ayam. Menurut Patterson dan Adrizal (2005) keberadaan gas-gas tersebut menyebabkan penurunan performa dan produktivitas ayam broiler, seperti penurunan laju pertumbuhan dan konversi pakan, serta timbulnya penyakit pada saluran pernafasan. Dampak bagi 
manusia diantaranya mata berair, bersinbersin, sakit leher, batuk kronis, sesak nafas, sakit kepala, dan mual (Golbabei dan Islami, 2000).

Prekursor utama pembentuk $\mathrm{NH}_{3}$ adalah asam urat, melalui aktivitas mikroba pengurai, baik secara aerobik maupun anaerobik (Koerkamp., 1994). Yusrizal et al. (2012) menyatakan bahwa $\mathrm{NH}_{3}$ pada kandang ayam terbentuk dari reaksi kimia antara asam urat $\left(\mathrm{C}_{5} \mathrm{H}_{4} \mathrm{~N}_{4} \mathrm{O}_{3}\right)$ dan air $\left(\mathrm{H}_{2} \mathrm{O}\right)$ serta enzim uricase asal bakteri gram (-). Konsentrasi $\mathrm{NH}_{3}$ yang sering kali cukup tinggi di kandang dapat menyebabkan produksi ayam menurun dan dapat membahayakan kesehatan pekerja kandang. Akumulasi ekskreta pada area terbuka merupakan sumber $\mathrm{NH}_{3}$ yang berpotensi mencemari lingkungan (Bittman dan Mikkelsen, 2009). Meskipun dalam kadar yang rendah, gas amonia juga menyumbangkan peningkatan suhu bumi (Santoso, 2009). Mengingat hal itu dibutuhkan teknologi untuk mengurangi emisi kadar $\mathrm{NH}_{3}$ di usaha peternakan ayam broiler. Salah satunya yaitu memperbaiki susunan ransum dengan memberi suatu penambahan bahan starter beberapa probiotik yang mempunyai mekanisme kerja spesifik sesuai dengan keunggulan masing-masing dan prebiotik untuk mengurangi bakteri gram negatif yang ada pada pencernaan ayam broiler yang dapat meminimalisir pembentukan amonia.

Dari beberapa hasil penelitian terdahulu diketahui bahwa suplementasi probiotik dapat mengubah pergerakan mucin dan populasi mikroba di dalam usus halus ayam, sehingga fungsi dan kesehatan usus serta uptake nutrien dapat ditingkatkan (Smirnov et al., 2005). Demikian pula hasil penelitian Mountzouris et al. (2010), menunjukan bahwa penambahan probiotik secara nyata dapat meningkatkan pertumbuhan ayam broiler. Hasil penelitian tersebut memberi indikasi bahwa probiotik memiliki peranan yang sangat berarti dalam menjaga keseimbangan mikroba di dalam saluran pencernaan unggas, sehingga dapat menjaga kesehatan ternak dan meningkatkan efesiensi penyerapan zat makanan yang pada akhirnya dapat mengurangi produksi ammonia yang berasal hasil dekomposisi limbah nitrogen dalam eskreta. Bakteri proteolitik seperti Bacillus sp. merupakan bakteri yang dapat mengahasilkan subtilin yang menurunkan jumlah mikroflora yang memproduksi enzim uricase dalam lumen saluran pencernaan (Visek et al., 1978), serta dapat menghambat konversi uric acid menjadi amonia dengan cara menggunakan uric acid sebagai zat nutrisinya (Santoso, 2009). Menurut Santoso (2009), Lactobacillus bulgaricus sebagai bakteri penghasil bacteorisin dapat menurunkan ammonia akibat kemampuannya dalam mencegah kelanjutan pertumbuhan Salmonella dan bakteri pathogenic gram (-) lainnya. Bakteri asam laktat Streptococcus thermophilus dalam saluran pencernaan akan menjadikan kondisi di dalam saluran pencernaan menjadi asam sehingga mempengaruhi proses metabolisme dari bakteri gram (-) dalam menghasilkan enzim uricase.

Mikroba probiotik yang sudah teridentifikasi pada umumnya berupa Bakteri Asam Laktat (BAL) dan beberapa genus Bacillus. Bacillus sebagai probiotik yang memiliki peranan luas, baik untuk mengatasi masalah pencemaran amonia pada kandang unggas maupun untuk memperbaiki efisiensi penggunaan nutrien pada ternak (Manin et al., 2012). Menurut Nastiti et al. (2013), fermentasi merupakan proses yang menggunakan mikroba sebagai fermentor atau inokulannya. Dengan fermentasi maka akan dapat meningkatkan kadar protein kasar dan menurunkan kadar SK (Ibrahim et al., 2015). Manin (2007), menemukan bakteri Bacillus (Bacillus cereus, B. mycoides, dan B.thuringiensis) dan Lactobacillus ( $L$. acidhophillus dan L. fermentum) pada ayam buras yang dipelihara di lahan gambut yang juga berpotensi sebagai sumber probiotik dan secara inderawi dapat mengurangi bau kandang dalam pemeliharaan ayam broiler. Dari penemuan ini terbuka peluang untuk mengkombinasikan berbagai bakteri Bacillus dan Lactobacillus sebagai probiotik yang 
Tabel 1. Emisi ammonia, $\mathrm{pH}$ dan kadar air feses pada akhir pemeliharaan

\begin{tabular}{lcc}
\hline Energi & Protein & Amonia Feses $(\mathrm{ppm})$ \\
\hline $3000 \mathrm{kkal} / \mathrm{kg}$ & 22 & $80,00^{\mathrm{a}}$ \\
& 20 & $13,33^{\mathrm{b}}$ \\
& 18 & $26,67^{\mathrm{b}}$ \\
\hline $2900 \mathrm{kkal} / \mathrm{kg}$ & 22 & $46,61^{\mathrm{b}}$ \\
& 20 & $30,00^{\mathrm{b}}$ \\
& 18 & $13,33^{\mathrm{b}}$ \\
\hline $2800 \mathrm{kkal} / \mathrm{kg}$ & 22 & $15,00^{\mathrm{b}}$ \\
& 20 & $15,00^{\mathrm{b}}$ \\
& 18 & $13,33^{\mathrm{b}}$ \\
\hline
\end{tabular}

memiliki peranan luas, baik untuk mengatasi masalah pencemaran amonia pada kandang unggas maupun untuk memperbaiki efisiensi penggunaan nutrien pada ternak.

Penelitian ini bertujuan untuk mengetahui dengan diberikan kombinasi level energi dan protein dengan bakteri Bacillus amyloliquefaciens dapat menurunkan amonia pada kandang ayam broiler.

\section{MATERI DAN METODE}

Penelitian ini menggunakan bakteri Bacillus amyloliquefaciens baik masingmasing perlakuan dengan menggunakan 2 faktor dan 3 ulangan yaitu Faktor A level energi (H1 $3000 \mathrm{kkal} / \mathrm{kg}$ ), (H2 $2900 \mathrm{kkal} / \mathrm{kg}$ ), (H3 $2800 \mathrm{kkal} / \mathrm{kg}$ ). Faktor B level protein (R1 $22 \%$ ), (R2 $20 \%$ ) dan (R3 18\%). Sebanyak 270 ekor Day Old Chicks CP 707 ditempatkan secara acak ke dalam 27 unit kandang, masingmasing sebanyak 10 ekor. Ayam dipelihara selama 5 minggu. Rancangan percobaan yang digunakan adalah Rancangan Acak pola faktorial $3 \times 3$ dengan 3 ulangan. Pada akhir minggu ke 5 pemeliharaan dilakukan pengambilan sampel feses untuk pengujian kadar amonia dan $\mathrm{pH}$. Sebanyak 50 gram feses diinkubasi selama 1 jam pada suhu ruang dan dilakukan pengukuran kadar ammonia.

\section{HASIL DAN PEMBAHASAN}

Pada akhir masa pemeliharaan, dilakukan pengambilan sampel feses, kemudian diinkubasi selama 1 jam untuk mengetahui efek penggunaan probiotik tersebut terhadap emisi ammonia, $\mathrm{pH}$ dan kadar air feses (Tabel 1).

\section{Kadar Ammonia}

Hasil analisis ragam menunjukan bahwa dengan menggunakan energi $3000 \mathrm{kkal} / \mathrm{kg}$ dengan protein $22 \%$ memberikan pengaruh yang nyata $(\mathrm{P}<0,05)$ menurunkan emisi amonia feses namun tidak nyata pemberian energi 2900 dan $2800 \mathrm{kkal} / \mathrm{kg}$ dengan protein $20 \%$ dan $18 \%$. Tidak berpengaruh nyata $(\mathrm{P}>$ $0,05)$ terhadap emisi ammonia feses.

Hasil penelitian pada Tabel 1 menunjukkan bahwa perlakuan dengan energi $2900 \mathrm{kkal}$ dan $2800 \mathrm{kkal} / \mathrm{kg}$ dengan protein $22 \%, 20 \%$ dan $18 \%$ berbeda nyata $(\mathrm{P}<0,05)$ dengan energi $3000 \mathrm{kkal} / \mathrm{kg}$ dan protein $22 \%$. Hal ini karena di dalam saluran pencernaan, bakteri bekerja secara spesifik dengan mekanisme fungsi masing - masing. Faktor utama yang menjadi pembentuk amonia yaitu uricase yang dihasilkan oleh bakteri gram negatif dan uric acid yang terbentuk karena protein yang tidak tercerna di dalam saluran pencernaan broiler. Chang et al. (1975) dalam Muller (1980), melaporkan bahwa dalam waktu 3,5 jam setelah koleksi, kadar amonia feses dapat meningkat lebih 
Vol. 20 (2): 99-107

Tabel 2. Ambang batas kadar $\mathrm{NH}_{3}$ pada ayam broiler

\begin{tabular}{ll}
\hline Kadar $_{3}(\mathrm{ppm})$ & \multicolumn{1}{c}{ Pengaruh } \\
\hline 20 & $\begin{array}{l}\text { Mengganggu kesehatan dan performa ayam broiler, meningkatnya } \\
\text { penyakit tetelo (New Castle Disease/ND) dan kerusakan sistem } \\
\text { pernafasan (dalam waktu lama) }\end{array}$ \\
\hline 25 & $\begin{array}{l}\text { Pertambahan bobot badan yang rendah, penurunan efisiensi pakan } \\
\text { (selama 42 hari), menyebabkan timbulnya airsacculitis yang diikuti } \\
\text { oleh infectious bursal disease (setelah 56 hari) }\end{array}$ \\
\hline $25-125$ & $\begin{array}{l}\text { Penurunan konsumsi pakan dan efisiensi pakan, menimbulkan gejala } \\
\text { keracunan pada ayam broiler meliputi iritasi pada trachea, radang } \\
\text { kantong udara, conjunctivity, dan dyspnea }\end{array}$ \\
\hline $75-100$ & $\begin{array}{l}\text { Perubahan epithelium pernafasan, termasuk hilangnya silia dan } \\
\text { meningkatnya jumlah sel pengeluaran lender }\end{array}$ \\
\hline $46-102$ & Menyebabkankerusakanpadamatadalambentuk keratokonjunctivitis \\
\hline
\end{tabular}

Sumber: Ritz et al. (2004)

dari enam kali lipat akibat terjadinya proses perombakan asam urat yang sangat cepat. Ditambahkan Sjofjan, (2003) semakin baik penyerapan protein maka produksi uric acid akan menurun, sehingga aktivitas penguraian uric acid menjadi amonia akan berkurang. Di samping itu probiotik juga dapat menahan akvitas mikroba pengurai protein pada feses dan litter sehingga menyebabkan kadar amonia menurun.

Terjadinya penurunan emisi ammonia feses menunjukan bahwa probiotik dapat bekerja menurut keunikannya masing-masing sehingga mampu menghambat pertumbuhan dan aktifitas mikroorganisme patogen yang dapat mengkonversi asam urat menjadi amonia. Bakteri proteolitik, seperti Bacillus $s p$., dapat menghambat konversi uric acid menjadi ammonia menjadi ammonia dengan menggunakan urid acid tersebut sebagai zat nutrisinya.

Seekor ayam broiler diperkirakan menghasilkan kotoran setiap harinya sebanyak $0,15 \mathrm{~kg}$ yang mengandung $1,7 \% 4$ nitrogen, $0,16 \%$ fosforus, dan $0,58 \%$ kalium (Kumar dan Biswar, 1982; Charles dan Hariono, 1991). Fontenot et al. (1983) melaporkan bahwa rata-rata produksi buangan segar ternak ayam petelur adalah $0,06 \mathrm{~kg} / \mathrm{hari} / \mathrm{ekor}$, dan kandungan bahan kering sebanyak 26\% sedangkan dari pemeliharaan ayam pedaging kotoran yang dikeluarkan sebanyak $0,1 \mathrm{~kg} /$ hari/ekor dan kandungan bahan keringnya $25 \%$.

Akumulasi ekskreta yang tidak segar dikelola sudah lama menjadi isu pada peternakan skala besar, terutama akibat bau $\left(\mathrm{NH}_{3}\right)$ yang ditimbulkan dapat mencemari lingkungan (NRC, 2003). Kemudian Kling and Quarles (1974) menyatakan bahwa sampai umur 8 minggu unggas yang stress akibat $\mathrm{NH}_{3}$ signifikan lebih rendah bobot badannya dibanding unggas yang tidak stress. Efek yang sangat merugikan dari emisi $\mathrm{NH}_{3}$ pada lingkungan dan performans ayam broiler serta kesehatan ternak sudah sangat diketahui. Threshold limit value (ambang batas $\mathrm{NH}_{3}$ ) di dalam kandang sebaiknya tidak lebih dari $25 \mathrm{ppm}$. Tetapi beberapa ilmuan eropa merekomendasikan ambang batas konsentrasi yang jauh lebih kecil yakni 10 ppm (Zuprizal, 2009), dan ambang batas kadar $\mathrm{NH}_{3}$ bagi manusia adalah 25 ppm selama 8-10 jam (Ritz et al., 2004). Unggas terpapar amonia dengan level $>25$ ppm dapat menyebabkan terjadinya kerusakan cilia dari trachea dan mudah terjadi penyakit seperti News Castle Deseases (ND), mengecilnya bursa of fabricus, sehingga menyebabkan terjadinya penurunan status kesehatan, tingkat performans dan 
Tabel 3. Efek paparan amonia terhadap manusia

\begin{tabular}{ll}
\hline Konsentrasi & Gejala yang Diperlihatkan \\
\hline $5 \mathrm{ppm}$ & Mulai terdeteksi \\
$6-20 \mathrm{ppm}$ & Iritasi mata, gangguan respirasi \\
$40 \mathrm{ppm}$ & Sakit kepala, mual, nafsu makan menurun \\
$100 \mathrm{ppm} / \mathrm{jam}$ & Iritasi pada permukaan mukosa \\
$400 \mathrm{ppm} / \mathrm{jam}$ & Iritasi pada hidung dan tenggorokan \\
\hline
\end{tabular}

Sumber: Pauzenga (1991)

produktivitas unggas. Demikian juga halnya bagi pekerja kandang, level ammonia yang tinggi dalam kandang dapat menyebabkan infeksi radang paru-paru (Yusrizal et al., 2012). Ditambahkan Pauzenga (1991), menyebutkan kandungan $\mathrm{NH}_{3}$ sebesar 5 ppm dalam kandang mulai menimbulkan iritasi pada mukosa mata dan saluran pernafasan (Chronic Respiratory Disease). Batas toleransi kadar $\mathrm{NH}_{3}$ pada ayam broiler disajikan pada Tabel 2 .

Selain mencemari lingkungan, gas NH3 juga dapat menurunkan penampilan ternak, meningkatkan kepekaan ternak terhadap penyakit serta menurunkan efisiensi kerja dari pekerja kandang (Charles dan Hariono, 1991). Ambang batas kadar $\mathrm{NH}_{3}$ pada manusia ditunjukkan pada Tabel 3.

Efek yang sangat merugikan dari emisi $\mathrm{NH}_{3}$ pada lingkungan dan performans ayam broiler serta kesehatan ternak sudah sangat diketahui. Untuk itu, pengontrolan $\mathrm{NH}_{3}$ pada kandang unggas sangat penting dilakukan untuk menjamin pengurangan emisi $\mathrm{NH}_{3}$ dan menciptakan lingkungan kandang yang lebih sehat. Dalam hal menurunkan $\mathrm{NH}_{3}$ feses dapat dilakukan dengan mengaplikasikan langsung (direct application) pada feses yang dikenal dengan post-excretion pathway. Selain itu, penurunan amonia juga dapat dilakukan dengan penanganan langsung ke sumber asal amonia yaitu melalui saluran pencernaan unggas yang dikenal metoda pre-excretion pathway. Salah satu cara yang dapat dilakukan dengan memanfaatkan komposisi unik bakteri khususnya bakteri yang memproduksi bakteriocin (antibiotik) dan enzim protease, serta bakteri yang mampu memfermentasi starch (karbohidrat) menjadi asam organic (Yusrizal et al., 2012). Namun kelemahannya yang harus segera diatasi adalah pelepasan ammonia feses setelah 24 jam inkubasi cenderung meningkat secara drastis. Hal ini disebabkan jumlah bakteri probiotik tersebut yang cenderung semakin menurun seiring bertambahnya waktu sehingga tidak efektif dan tidak cukup lagi jumlahnya untuk memproduksi asam dan antibiotik untuk menekan bakteri gram (-) yang berperan dalam menghasilkan ammonia. Untuk mengurangi pencemaran ammonia adalah dengan memanfaatkan berbagai spesies mikroba unggul terseleksi sebagai sumber probiotik (Manin et al., 2012) yang dapat mengubah pergerakan mucin dan populasi mikroba di dalam usus halus ayam, sehingga fungsi dan kesehatan usus serta uptake nutrien dapat ditingkatkan (Smirnov et al., 2005), dan kadar $\mathrm{NH}_{3}$ akan berkurang (Adrizal et al., 2011; Yusrizal et al., 2013).

\section{Derajat Keasaman (pH)}

Hasil analisis ragam (Tabel 4) menunjukan bahwa pemberian ransum yang menggunakan energi dan protein yang berbeda memiliki spesifik masing-masing berbeda nyata $(\mathrm{P}<0,05)$ terhadap derajat keasaman $(\mathrm{pH})$. Ekskreta mempunyai kisaran $\mathrm{pH}$ antara 8,38-8,39 dan litter $\mathrm{pH}$ berkisar antara 5-6,5 (Weaver, 2001).

Tabel 4 menunjukkan bahwa Penurunan $\mathrm{pH}$ pada feses yang mendapat probiotik diduga akibat dihasilkannya asam organik oleh BAL serta berkurangnya perombakan protein menjadi amonia dan proses fermentasi yang menjadikan kondisi 
Vol. 20 (2): 99-107

Tabel 4. Derajat keasaman $(\mathrm{pH})$ dan kadar air feses

\begin{tabular}{lccc}
\hline Energi & Protein & Kadar Air feses & $\mathrm{pH}$ feses \\
\hline $3000 \mathrm{kkal} / \mathrm{kg}$ & 22 & $73,84^{\mathrm{a}}$ & $7,86^{\mathrm{a}}$ \\
& 20 & $75,58^{\mathrm{a}}$ & $6,10^{\mathrm{d}}$ \\
& 18 & $70,91^{\mathrm{bc}}$ & $7,43^{\mathrm{ab}}$ \\
\hline $2900 \mathrm{kkal} / \mathrm{kg}$ & 22 & $75,77^{\mathrm{a}}$ & $6,93^{\mathrm{bc}}$ \\
& 20 & $74,16^{\mathrm{ab}}$ & $7,36^{\mathrm{ab}}$ \\
& 18 & $70,59^{\mathrm{b}}$ & $5,63^{\mathrm{de}}$ \\
\hline $2800 \mathrm{kkal} / \mathrm{kg}$ & 22 & $71,93^{\mathrm{bc}}$ & $5,13^{\mathrm{e}}$ \\
& 20 & $73,34^{\mathrm{ab}}$ & $5,86^{\mathrm{de}}$ \\
& 18 & $67,49^{\mathrm{c}}$ & $6,36^{\mathrm{cd}}$ \\
\hline
\end{tabular}

asam. Sembiring (2001) menyatakan bahwa aktivitas mikroorganisme dapat menyebabkan perubahan $\mathrm{pH}$ karena substrat yang dihasilkan oleh mikrobia. Proses fermentasi oleh bakteri akan menghasilkan asam sehingga $\mathrm{pH}$ dapat turun, sebaliknya sewaktu metabolisme protein dan asam amino akan dilepaskan ion amonium sehingga $\mathrm{pH}$ menjadi basa. Penurunan $\mathrm{pH}$ feses erat kaitannya dengan dihasilkannya asam oleh bakteri asam laktat. Seperti yang dikemukakan oleh Lopez (2000), bahwa salah satu mekanisme kerja probiotik adalah menghasilkan asam sehingga akan menurunkan $\mathrm{pH}$ di dalam saluran pencernaan. Dengan menurunnya $\mathrm{pH}$ di dalam saluran pencernaan maka $\mathrm{pH}$ feses pun akan menurun. Mobley dan Hausinger (1989) menyatakan bahwa $\mathrm{pH}$ feses sangat berperan dalam pelepasanamonia pada feses, sebab penurunan $\mathrm{pH}$ manure akan merubah keseimbangan amonia $\left(\mathrm{NH}_{3}\right)$ menjadi amonium $\left(\mathrm{NH}_{4}^{+}\right)$yang lebih larut dalam air sehingga tidak mudah menguap dibanding amonia $\mathrm{NH}_{3}$.

Fungsi bakteri dari asam laktat ini menurunkan $\mathrm{pH}$ lingkungan menjadi 3 sampai 4,5 sehingga pertumbuhan bakteri lain termasuk bakteri pembusuk akan terhambat (Rostini, 2007). pH optimum diperlukan untuk produksi antibakteri karena $\mathrm{pH}$ sangat berpengaruh dalam pembentukan bakteriosin optimum pada pH 5 dan 6 pada media MRS (Mogjani dan Amirnia, 2007). Peningkatan pH sampai $\mathrm{pH}$ optimum menghasilkan produksi bakteriosin yang maksimal, sementara itu faktor suhu memiliki dua pengaruh yang bertentangan yaitu meningkatkan produksi bakteriosin tetapi juga bisa membunuh BAL penghasil bakteriosin (Januarsyah, 2007).

Menurut Zuprizal (2009), pH dan kadar amonia saling berhubungan, konsentrasi amonia dalam kandang terkait erat dengan banyaknya konsentrasi nitrogen dalam kotoran, $\mathrm{pH}$, dan sistem ventilasi. Konsentrasi nitrogen dalam kotoran diakibatkan oleh banyaknya kandungan protein dalam ransum yang tidak tercerna dengan sempurna, sehingga dengan adanya konsentrasi nitrogen maka konsentrasi amonia pun meningkat karena adanya aktivitas bakteri yang mengurai nitrogen dalam kotoran ungggas menjadi gas amonia. Apabila kadar amonia tinggi maka $\mathrm{pH}$ pun akan meningkat, hal ini dipengaruhi oleh semakin banyaknya ekskreta yang dihasilkan oleh ayam dan aktivitas bakteri dalam mengurai nitrogen menjadi asam urat.

\section{Kadar Air Amonia}

Bila diamati dari data kadar air bahwa probiotik $B$. amyloliquefaciens berpengaruh nyata $(\mathrm{P}<0,05)$ terhadap kadar air. Pada Tabel 1 dapat dilihat bahwa kadar air feses pada ayam yang diberi probiotik sangat berpengaruh terhadap pertumbuhan ayam. Hasil penelitian Yusrizal et al. (2012), terjadinya penurunan kadar air disebabkan bahan fermentasi merupakan serbuk BIS yang mempunyai kadar air cukup rendah karena hasil pengeringan di oven sebelum digunakan. 
Jadi perlakuan fermentasi kalau dicampurkan dengan feses akan dapat menyerap kadar air feses. Kadar air yang diproduksi pada ekskreta broiler berkisar antara $60-80 \%$ (Leeson dan Summers, 2000).

Kontribusi nyata dari pemberian bakteri probiotik yaitu dengan menekanjumlah bakteri patogen dalam saluran pencernaan. Penurunan kadar amonia, $\mathrm{pH}$ dan kadar air dalam saluran pencernaan itu sejalan. Tingginya kadar air akan menyebabkan pertumbuhan bakteri patogen semakin meningkat dikarenakan kondisi $\mathrm{pH}$ dalam saluran pencernaan masih belum optimal (basa), sehingga perlu diciptakan kondisi asam untuk menekan pertumbuhan bakteri patogen yang nantinya perombakan uricase pembentuk amonia semakin meningkat. Yusrizal et al. (2012) menyatakan bahwa kandungan air yang cukup tinggi dapat menyebabkan aktivitas mikroorganisme patogen (E. Coli) bekerja efektif sehingga emisi $\mathrm{NH}_{3}$ yang diproduksi juga akan meningkat.

\section{KESIMPULAN}

Interaksi antara level energi dan level protein yang dilakukan bahwa interaksi energi $2800 \mathrm{kkal} / \mathrm{kg}$ dengan protein $18 \%$ yang dibantu oleh bakteri Bacillus amyloliquefaciens sebagai probiotik berpotensi untuk mengurangi pencemaran amonia pada kandang ayam broiler.

\section{DAFTAR PUSTAKA}

Adrizal, A., Y. Yusrizal., S. Fakhri., W. Haris., E. Ali and C. R. Angel. 2011. Feeding native laying hens diets containing palm kernel meal with or without enzyme supplementations: 1. Feed conversion ratio and egg production. Poultry Science Association, Inc., 20, $40-49$.

Bittman, S., and R. Mikkelsen. 2009. Ammonia emissions from agricultural operations: livestock. Better Crops
93:28-31.

Chang., T dan Wildt, A. R. 1975. -D liquefaction potensial Ananlysis of Seabed at Nearshore Area. Journal of Marine Science and Techology. 12 (3): 141-51

Charles. R. T. dan B. Hariono. 1991. Pencemaran Lingkungan oleh limbah peternakan dan pengelolaannya. Bull. FKH - UGM X (2) : 71 - 75

Chiang, S.H. and W.M. Hsieh. 1995. Effect of Direct Fed Microorganisms on Broiler Growth Performance and Liter Ammonia Level Asian-Australian $J$. Anim. Sci.8:169-162

Fontenot, J. P., W. Smith, and A. L. Sutton. 1983. Altenatif utilization of animal waste, J. Anim. Sci. 57: 221-223.

Golbabei, F. and F. Islami. 2000. Evaluation of worker's exposure to dust, ammonia and endotoxin in poultry industries at the province of Isfahan, Iran. Industrial Health. 38 : 41-46.

Ibrahim, W., Mutia, R. and Nurhayati. 2015. Use of fermented pineapple peel in the ration containing medicinal weeds on fat and cholesterol of broiler chicken. Agripet: Vol (14) No. 1 : 20-27

Januarsyah, T. 2007. Kajian aktivitas hambat bakteriosin dari bakteri asam galur SCG 1223. Skripsi. Institut Pertanian Bogor. Bogor

Kumar S, and T. D. Biswar. 1982. Biomass production from different animal excreta. J. Indian Agr. Sci. 51: 513-520.

Koerkamp, P. W. G. 1994. Review on emissions of ammonia from housing systems for laying hens in relation to sources, processes, building design and manure handling. J. Agric. Engng. Res. 59:73-87.

Kling, H. F. and C. L. Quarles, 1974. Effect of atmospheric ammonia and the stress of infectious bronchitis vaccination on Leghorn males. Poultry Sci. 53: 11611167. 
Lesson, S. and J. D. Summer. 2000. Comercial Poultry Nutrition. 2nd Ed. University Book. University Guelph. Guelph, Ontario, Canada.

Lopez, J. 2000. Probiotic in animal nutrition. Recent Advances in Animal Nutrition Asian-Australian Journal of Animal Science 55: 1238-1246.

Manin. F., Ella Hendalia, dan A. Aziz . 2007. Isolasi dan Produksi Isolate Bakteri Asam Laktat dan Bacillus sp dari Saluran Pencernaan Ayam Buras Asal Lahan Gambut Sebagai Sumber Probiotik. Jurnal AGRITEK (Jurnal Ilmu-Ilmu Pertanian, Teknologi Pertanian dan Kehutanan). Terakreditas No.026/Dikti/Kep/2005. Agritek Edisi Khusus Dies Natalis IPM Ke-16 November 2007. Halaman 74-78.

Manin, F., Ella H, Yusrizal, dan Yatno. 2010. PenggunaanSimbiotik yang Berasal dari Bungkil Inti Sawit dan Bakteri Asam Laktat Terhadap Performans, Lingkungan dan Status Kesehatan Ayam Broiler.Laporan Penelitian Strategi Nasional.

Manin. F, Ella H., Yatno dan Pudji Rahayu. 2012. Dampak pemberian probiotik probio_FM terhadap kinerja itik Kerinci jantan. Prosiding Seminar Nasional Peternakan Berkelanjutan "Peningkatan Produktivitas Sumber Daya Peternakan, Bandung, 12 November 2013. Hal. 235-239.

Muller, Z.O. 1980. Feed from Animal Waste: State of Knowledge. Food and Agriculture Organization of The United Nations, Rome.

Murtidjo, B. A. 2003. Pedoman Beternak Ayam Broiler . Kanisius. Yogyakarta.

Mobley, D. F., and R. P. Hausinger. 1989. Microbial ureases: singnificance, regulation, amoleculercharacterization. Micbiol. Rev. 53:85-108.

Mojgani, N. and C. Amirnia. 2007. Kinetics of Growth and bacteriocin production in L. casei RN 78 isolated from a dairy sample in IR Iran. International journal of Dairy science 2(1): 1-12

Mountzouris K.C.P. Tsitrisikos, I. Palamidi, A. Arvaniti, M. Mohnl, G. Schatzmayr and K. Fegeros. 2010. Effect of probiotic inclusion levels in broiler nutrion on growth performance, nutrient digestibility, plasma immunoglobulins and cecal microflora composition Poult. Sci. 89:58-67.

Nastiti,U. N., Lastuti, N.D.R., Nurhajato. and T. 2013. The decreasing of crude fiber and the increasing of crude ptotein content of pineapple (Ananas comosus L, Merr) which fermented by cellulolytic bacteria (Actinobacillus sp. ML-08). Jurnal Agroveteriner. 1 (2): 46-54.

Patterson, P. H. and Adrizal. 2005. Management Strategies To Reduce Air Emissions: Emphasis - Dust And Ammonia. J. Appl. Poult. Res. 14 : 638650.

Pauzenga. 1991. Animal Production in the 90's in harmony with Nature, a Case Study in Nederlands. Nicholasville. Kentucky.

Ritz, C. W, B. D. Fairchild. and M. P. Lacy. 2004. Implications of ammonias production and emissions from commercial poultry facilities: A Review. J. Appl. Poult. Res. 13 : 684692.

Rostini, I. 2007. Kultur fitoplankton(Chlorella sp. dan Tetraselmis chuii) pada skala laboratorium. Skripsi. Jatinagor: Universitas Padjajaran. $33 \mathrm{hlm}$.

Santoso, U.S. Ohtani, K., Tanaka dan Sakaida. 1999. Dried Bacillus subtillis Culture reduced ammonia gass release in poultry house. AsianAustralian Journal of Animal Sciences (AJAS) Vol. 12. No. 5. 677-842.

Sembiring, P. 2001. Biokonversi limbah pabrik minyak inti sawit dengan Phanerochaete chrysosporium dan

Pengaruh Level energi dan ... (Riza et al.) 
implikasinya terhadap performans ayam broiler. Disertasi. UNPAD. Bandung.

Sjofjan, O. 2003. Kajian probiotik (Aspergillus niger dan Bacillus spp) sebagai imbuhan ransum dan implikasi efeknya terhadap mikroflora usus serta penampilan produksi ayam petelur. Disertasi. Universitas Pajajaran, Bandung.

Smirnov A.,R. Perez, E.Amit-Romach, D.Sklan, and Z. Uni. 2005. Mucin dynamics and microbial populations in chicken small intestine are changed by dietary probiotic and antibiotic growth promoter supplementation. J.Nutr.135:187-192.

Visek, W. I. 1978. The mode of growth promotion by antibiotics. J. Anim. Sci., 46: 1447-1469.

Weaver, J. R. W . D. 2001. Fundamentals of Ven tilation, in Commercial Chicken Meat and Egg Production. United State of America .

Yusrizal, F. Manin, Yatno and Noverdiman. 2012. The use of probiotic and prebiotic (symbiotic) derived from palm kernel cake in reducing ammonia emission in the broiler house.Proc. The 1st Poult Int.Sem 2012. P : 3334343. ISBN 798602-969334-6-1.

Yusrizal Y. 2013. Microbial and oligosaccharides treatments of feces and slurry in reducing ammonia of the poultry farm. Media Peternakan. pp. $152-156$

Zuprizal. 2009. Industri Pakan Ternak di Indonesia: Tinjauan dari Penggunaan Makronutrien Protein Pakan. Pidato Pengukuhan Jabatan Guru Besar pada Fakultas Peternakan Universitas Gadjah Mada. Yogyakarta: UGM. 